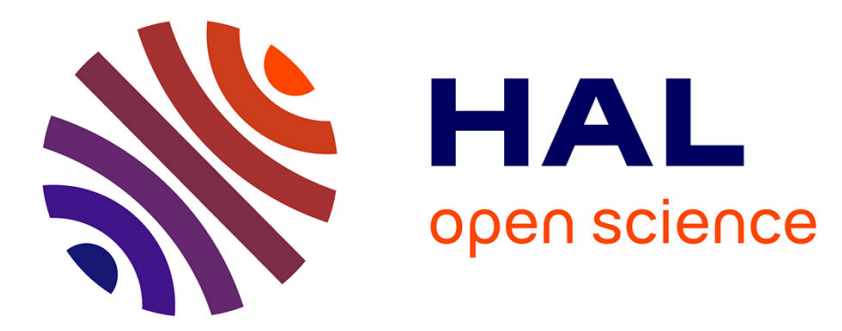

\title{
Influence of calcium on glucose biosensor response and on hydrogen peroxide detection
}

\author{
Nathalie Labat-Allietta, Daniel R. Thevenot
}

\section{To cite this version:}

Nathalie Labat-Allietta, Daniel R. Thevenot. Influence of calcium on glucose biosensor response and on hydrogen peroxide detection. Biosensors and Bioelectronics, 1998, 13 (1), pp.19 - 29. 10.1016/S09565663(97)00084-5 . hal-01084657

\section{HAL Id: hal-01084657 \\ https://hal-enpc.archives-ouvertes.fr/hal-01084657}

Submitted on 19 Nov 2014

HAL is a multi-disciplinary open access archive for the deposit and dissemination of scientific research documents, whether they are published or not. The documents may come from teaching and research institutions in France or abroad, or from public or private research centers.
L'archive ouverte pluridisciplinaire HAL, est destinée au dépôt et à la diffusion de documents scientifiques de niveau recherche, publiés ou non, émanant des établissements d'enseignement et de recherche français ou étrangers, des laboratoires publics ou privés.

\section{(c)(1)}

Distributed under a Creative Commons Attribution| 4.0 International License 


\title{
Influence of calcium on glucose biosensor response and on hydrogen peroxide detection
}

\author{
Nathalie Labat-Allietta \& Daniel R. Thévenot
}

Laboratoire de Bioélectrochimie et Analyse du Milieu (LABAM), Faculté de Sciences et Technologie, Université Paris X.II-Val de Marne, 61 Avenue du Général de Gaulle, 94010 Créteil, Cedex France

(Received 17 January 1996; revised version received 24 March 1997; accepted 25 July 1997)

\begin{abstract}
Of small species capable of reaching a platinum working electrode from biological samples, calcium cations have been found to inhibit significantly glucose biosensor responses. The sensitivities to glucose of sensors immersed in carbonate buffer saline solutions decreased when $0.5 \mathrm{mM}$ calcium chloride was added. The degree of inhibition was proportional to the glucose response in the absence of calcium $(0-17 \%$ of the normalized current). Likewise, sensor sersitivities to hydrogen peroxide decreased, in the 5-90\% range, in the presence of $0.5 \mathrm{mM}$ calcium.

Bare Pt-Ir wires show a reversible inhibition of hydrogen peroxide sensitivity. This reversible inhibition is directly related to the decrease of hydrogen peroxide oxidation rate at the platinum anode: this has been evidenced, using rotating disk electrodes, by plotting Koutecky-Levich plots. Such inhibition has been found both for free and chelated calcium cations at levels below $1 \mathrm{mM}$.

Several hypotheses for possible reactions between platinum, hydrogen peroxide and calcium are discussed. (C) 1997 Elsevier Science Limited. All rights reserved.
\end{abstract}

Keywords: glucose sensor, calcium, hydrogen peroxide, Koutecky-Levich plots, platinum

\section{INTRODUCTION}

Among the numerous applications of biosensors, the development of an implantable sensor for glucose has been one of the most challenging and most studied problems (Wilson et al., 1991). Most glucose biosensors have a reliable in vitro response but show some problems when implanted. They generally demonstrate two effects of this implantation: an important reduction $(50-80 \%)$ of their sensitivity to glucose; and an important increase $(2-4 \mathrm{~h})$ of the time necessary for obtaining a steady-state response, i.e. the run-in time.

As stated by a recent European Survey conducted by Pickup \& Thévenot (1993), these modifications have been observed, to differing degrees, by several research groups having realized in vivo evaluations of subcutaneously implantable glucose sensors (Fischer et al., 1987; Pickup et al., 1989; Mascini \& Selleri, 1989; Koudelka et al., 1991). Many authors attempted to explain these observations by a modification of surrounding tissue properties (Fischer et al., 1987), the outer membrane fouling by protein adsorption (Shichiri et 
al., 1982; Hanning et al., 1986) or even by the inhibition of the biological part of biosensors. But few of them have shown interest in the electrochemical transducer and the detection of the enzyme reaction product, here hydrogen peroxide. In this study, we demonstrate that, in the case of a glucose biosensor, the electrochemical transducer may be incriminated. As do Lobel \& Rishpon (1981) and Kerner et al. (1993), we think that modification of $\mathrm{H}_{2} \mathrm{O}_{2}$ detection could be explained only by the action of small molecules able to reach the platinum electrode. We show here that, among biological ionic constituents, calcium may interfere with the anodic oxidation rate of hydrogen peroxide.

\section{EXPERIMENTAL}

\section{Glucose sensor}

Glucose sensor and sensing layer fabrication have been described previously (Bindra et al., 1991). The sensing part is situated $3-4 \mathrm{~mm}$ from the tip and presents a cylindrical cavity of 1-2 mm in length (Fig. 1). The working cathode is a $0.17 \mathrm{~mm}$ diameter Pt-Ir wire (Medwire, Mount Vernon, NY). The sensing cavity is covered with three layers of cellulose acetate (CA), a layer of glucose oxidase (EC 1.1.3.4) (Aspergillus niger, Boehringer, grade II, $230 \mathrm{U} / \mathrm{mg}$ ) reticulated with glutaraldehyde (GA) and bovine serum albumin (BSA) and, finally, two layers of polyurethane (PU type SG 85A) (Thermedics, Woburn, MA). To prevent glucose sensor responses from acetaminophen interference, supplementary Nafion layers are deposited together with CA ones (Zhang et al., 1994). A silver-silver chloride auxiliary refer- ence electrode ( $100 \mu \mathrm{m}$ outer diameter; Aldrich) is wrapped around the Teflon-coated Pt-Ir wire. The overall diameter of the sensor is $0.25 \mathrm{~mm}$ for the sensing part and $0.45 \mathrm{~mm}$ for the reference electrode part.

\section{Sensor calibration}

The sensor was dipped into a $37^{\circ} \mathrm{C}$ thermostatted cell containing $5 \mathrm{ml}$ of stirred $0.027 \mathrm{M}$ carbonate, $0.15 \mathrm{M} \mathrm{NaCl}, \mathrm{pH} 7.4$ buffer saline solution (CBS). A $650 \mathrm{mV}$ potential difference was applied between the working and reference electrodes of the sensor, for hydrogen peroxide detection. Amperometry was performed by using a Tacussel (Villeurbanne, France) Model PRGE or PRG-DEL detector. Current-time curves were recorded on a Lineis (Selb, Germany) Model L6514 4 channel strip-chart recorder. After stabilization of the background current $(30 \mathrm{~min}$ in CBS), standard additions of glucose were performed in order to vary the glucose concentration in the $3-15 \mathrm{mM}$ range.

\section{Calcium dependence of glucose sensor response}

All these assays were performed in air saturated CBS, using glucose sensors whose sensitivity to glucose ranged between 1.5 and $30 \mathrm{nA} / \mathrm{mM}$ (Table 1).

Sensor responses to glucose or hydrogen peroxide standard additions were determined in twostep experiments (Fig. 2). After stabilization of the background current in CBS, either $3 \mathrm{mM}$ glucose or $20 \mu \mathrm{M}$ hydrogen peroxide was added and corresponding steady-state responses determined. Then $0.5-2 \mathrm{mM} \mathrm{CaCl}_{2}$ was added to the

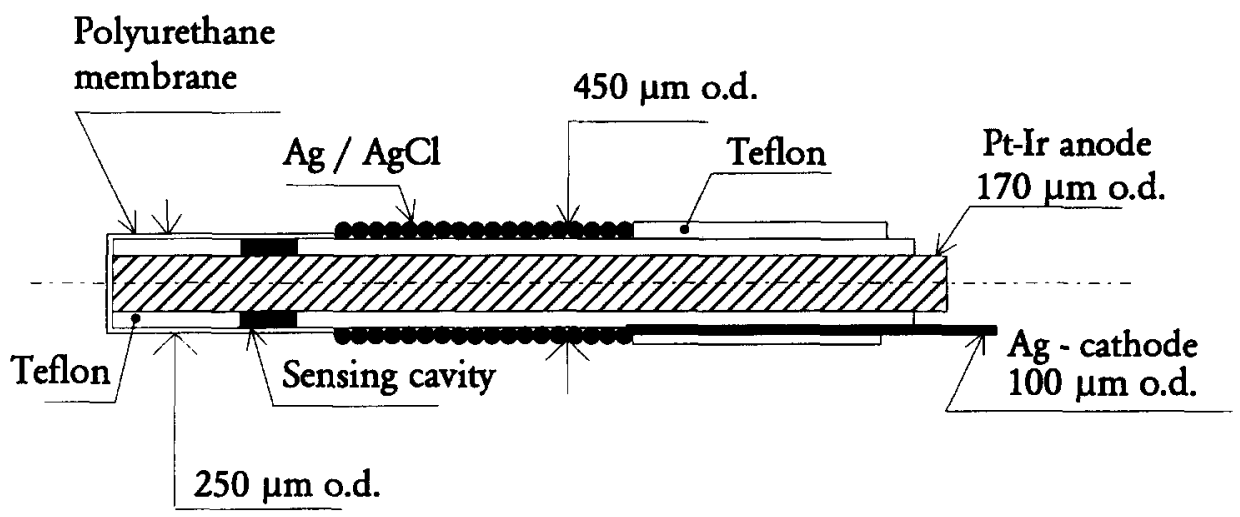

Fig. I. Schematic diagram of the glucose sensor. 
TABLE 1 Analytical parameters of glucose sensors and $\mathrm{Pt}-\mathrm{Ir}$ anodes used in this study

\begin{tabular}{|c|c|c|c|}
\hline Type of electrode & Analytical parameter & Unit & Range \\
\hline \multirow{5}{*}{ Glucose sensors } & Sensitivity to glucose & $\left(\mathrm{nA} \mathrm{mM}-1 \mathrm{~mm}^{-2}\right)$ & $1-16$ \\
\hline & Maximum glucose for $90 \%$ linearity & $(\mathrm{mM})$ & $3-12$ \\
\hline & $90 \%$ response time to glucose & (s) & $60-180$ \\
\hline & Sensitivity to $\mathrm{H}_{2} \mathrm{O}_{2}$ & $\left(\mathrm{~mA} \mathrm{mM}^{-1} \mathrm{~mm}^{-2}\right)$ & $0.06-0.25$ \\
\hline & $90 \%$ response time to $\mathrm{H}_{2} \mathrm{O}_{2}$ & (s) & $30-50$ \\
\hline Bare Pt-Ir wires & Sensitivity to $\mathrm{H}_{2} \mathrm{O}_{2}$ & $\left(\mathrm{~mA} \mathrm{mM}^{-1} \mathrm{~mm}^{-2}\right)$ & $2 \cdot 5-6 \cdot 7$ \\
\hline Polished rotating Pt disk & $\begin{array}{c}\text { Sensitivity to } \mathrm{H}_{2} \mathrm{O}_{2} \text { (extrapolated at infinite } \\
\text { r.p.m.) }\end{array}$ & $\left(\mathrm{mA} \mathrm{mM}^{-1} \mathrm{~mm}^{-2}\right)$ & $3 \cdot 5-6 \cdot 2$ \\
\hline Unpolished rotating $\mathrm{Pt}$ disk & $\begin{array}{c}\text { Sensitivity to } \mathrm{H}_{2} \mathrm{O}_{2} \text { (extrapolated at infinite } \\
\text { r.p.m.) }\end{array}$ & $\left(\mathrm{mA} \mathrm{mM}^{-1} \mathrm{~mm}^{-2}\right)$ & $1 \cdot 1-2 \cdot 1$ \\
\hline
\end{tabular}

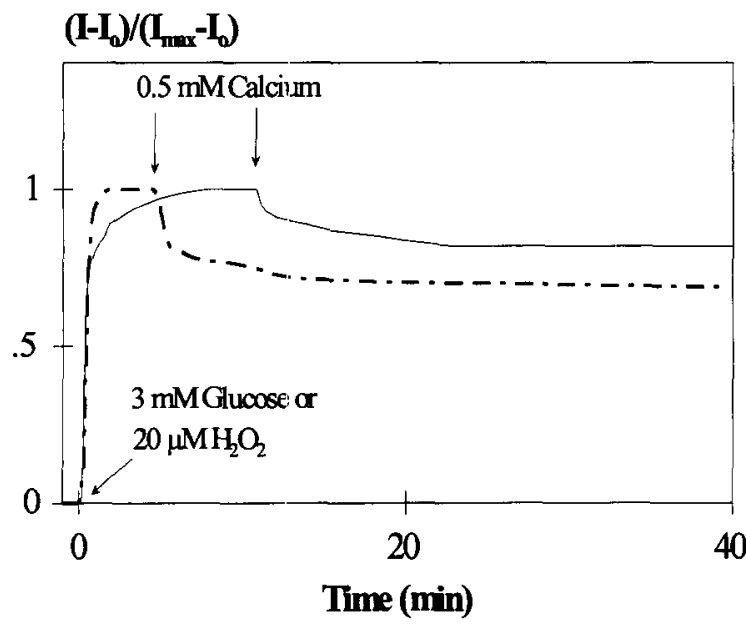

Fig. 2. Relative glucose sensor responses to successive additions of either (- $3 \mathrm{mM}$ glucose or 1 -) $20 \mu \mathrm{M} \mathrm{H}_{2} \mathrm{O}_{2}$ and then $0.5 \mathrm{mM} \mathrm{CaCl}$ in $\mathrm{CBS}$ solution. Currents have been corrected for background signal $I_{0}$ and normalized, i.e. divided by $I_{\max }-I_{0}$, in order to show calcium dependence of both glucose and hydrogen peroxide responses.

previous solution and sensor response recorded until a new steady-state response was attained: calcium addition usually yielded a slow but significant decrease of the current. The sensor was rinsed thoroughly in CBS solutions before a further experiment: with a different calcium concentration.

\section{Calcium dependence of bare Pt-Ir wires' response to $\mathrm{H}_{2} \mathrm{O}_{2}$}

Pt-Ir wires responses to $\mathrm{H}_{2} \mathrm{O}_{2}$ standard additions were determined in CBS solutions. After stabilization of the background current, three additions of $2 \mu \mathrm{M} \mathrm{H} \mathrm{H}_{2} \mathrm{O}_{2}$ or one addition of $20 \mu \mathrm{M} \mathrm{H} \mathrm{H}_{2} \mathrm{O}_{2}$ (final concentration) were performed and corresponding steady-state responses determined. Then $\mathrm{H}_{2} \mathrm{O}_{2}$ responses were determined in CBS solutions containing $0.5-2.5 \mathrm{mM}$ calcium, each calibration curve being obtained at a constant calcium concentration. The sensors were rinsed thoroughly in CBS solutions before a further assay using a different calcium concentration. These responses were compared to the original ones obtained in the absence of calcium. $\mathrm{H}_{2} \mathrm{O}_{2}$ concentrations were chosen for obtaining response values close to the $5 \mathrm{mM}$ glucose ones for glucose sensors, i.e. in the $2-20 \mu \mathrm{M}$ range. $\mathrm{Pt}-\mathrm{Ir}$ wires used for this study present $\mathrm{H}_{2} \mathrm{O}_{2}$ sensitivities ranging between 2.5 and $6.7 \mathrm{~mA} \mathrm{mM}^{-1} \mathrm{~mm}^{-2}$ (Table 1 ).

\section{Calcium dependence of rotating $\mathrm{Pt}$ disk response to $\mathrm{H}_{2} \mathrm{O}_{2}$}

The rotating disk electrode (RDE) with a $2 \mathrm{~mm}$ diameter Pt rod and the motor controller (EDI and Controvit Radiometer-Tacussel, Villeurbanne, France) were associated to a potentiostat (PRGDEL, Radiometer-Tacussel) except for voltamperometry, which was performed on a PRGE model. In some experiments, the RDE was first polished with $5 \mu \mathrm{m}$ alumina paper (RadiometerTacussel) at 600 r.p.m. for $1 \mathrm{~min}$ and rinsed with distilled water. Then the RDE was polished again with $0.3 \mu \mathrm{m}$ diamond paper under the same conditions, followed by a thorough rinsing with deionized water. All these RDE experiments were performed at $25^{\circ} \mathrm{C}$ using a $\mathrm{Ag} / \mathrm{AgCl} / \mathrm{sat} . \mathrm{KCl}$ reference electrode (Radiometer-Tacussel $\mathrm{AgCl10}$ ) in CBS after stabilization of background current. Two or $20 \mu \mathrm{M}$ hydrogen peroxide and 
$0.5 \mathrm{mM}$ calcium chloride spikes were added to the vessel, before scanning the disk rotation rate in the 100-5000 r.p.m. range in six successive steps.

\section{Chelatant effect on calcium inhibition of rotating $P t$ disk response to $\mathrm{H}_{2} \mathrm{O}_{2}$}

Experiments were performed at $25^{\circ} \mathrm{C}$ in CBS either on glucose sensors or on polished RDEs at 1250 r.p.m. disk rotation rate. After stabilization of background current, $20 \mu \mathrm{M}$ hydrogen peroxide spikes were added to the cell and the corresponding steady state determined. Then addition of different chelating agents was performed and the new steady-state response recorded. The chelating solutions tested were: $0.5-1 \mathrm{mM}$ lactic acid, $0.2-0.4 \mathrm{mM} \beta$ hydroxybutyric acid, 0.03-0.06 mM pyruvic acid, 0.2-0.4 $\mathrm{mM} \alpha$ ketoglutaric acid, $0.25-0.75 \mathrm{mM}$ EDTA, 0.25-3 mM citric acid and $0.25-0.75 \mathrm{mM}$ oxalic acid. Same experiments were performed in the presence of $0.5 \mathrm{mM}$ calcium.

\section{RESULTS AND DISCUSSION}

\section{Glucose sensor response in the presence of calcium}

Among ionic constituents of biological fluids, i.e. human blood serum or interstitial liquid, which are not taken into account in our PBS and CBS solutions, calcium is clearly the most significant. Its total concentration in blood plasma or extracellular fluid is normally $2.50 \mathrm{mM}$. Within this amount, a large fraction is bound to proteins $(1.0 \mathrm{mM})$, i.e. albumin $(0.7 \mathrm{mM})$ and globulins (Siggaard-Andersen et al., 1983a). Another fraction, i.e. $0.25 \mathrm{mM}$, is bound to anions such as bicarbonate, lactate or citrate. The rest, i.e. $1.25 \mathrm{mM}$, is the so-called 'ionized calcium' which itself contains $0.38 \mathrm{mM}$ 'active calcium'. The ionized calcium level has been assessed as a function of total calcium, total protein and $\mathrm{pH}$ (SiggaardAndersen et al., 1983b).

In order to avoid possible precipitation of calcium carbonate or hydroxide in CBS containing calcium levels that were too high, we performed multi-equilibrium calculations taking into account $\mathrm{H}^{+}, \mathrm{OH}{ }^{-}, \mathrm{Na}^{+}, \mathrm{Ca}^{2+}, \mathrm{Cl}{ }^{-}, \mathrm{H}_{2} \mathrm{CO}_{3}, \mathrm{HCO}_{3}{ }^{-}$, $\mathrm{CO}_{3}{ }^{2-}, \mathrm{CaOH}^{+}, \mathrm{CaHCO}_{3}{ }^{+}, \mathrm{CaCO}_{3, \mathrm{aq}}, \mathrm{CaCO}_{3, \text { solid }}$, $\mathrm{Ca}(\mathrm{OH})_{2, \text { aq }}, \mathrm{Ca}(\mathrm{OH})_{2, \text { solid }}$ and $\mathrm{CO}_{2, \text { gas }}$ as possible species and their stability constants (Charlot, 1969; Kotrly \& Sucha, 1985; Sigg et al., 1992). We used a software, named CINEQ, developed by Jean-Marie Mouchel (CERGRENE, ENPC, Marne la Vallée, France) for multi-equilibrium and kinetics calculation. If no exchange between the solution and the atmosphere is taken into account, i.e. if total carbonate concentration is maintained at $27 \mathrm{mM}$, solid calcium carbonate is absent, as well as calcium hydroxide, as long as total calcium content is, at $\mathrm{pH} 7.4$, below $0.8 \mathrm{mM}$. If carbon dioxide is in equilibrium with the atmosphere and partially expelled, which is likely to occur after a few hours stirring CBS in open vessels, then total carbonate concentration decreases below $27 \mathrm{mM}$ and, consequently, maximum level of calcium without solid formation increases, reaching $1 \mathrm{mM}$. Taking into account these data, we have generally studied glucose sensor operating behaviour in CBS containing $0.5 \mathrm{mM}$ calcium chloride.

In order to visualize possible deposits of $\mathrm{CaCO}_{3}$ precipitate on the electrode surface, microscopic observations were realized. Three PtIr wires were observed under optical microscopy (magnification 100) in CBS, spiked with 0.5$2.5 \mathrm{mM}$ calcium (final concentration). After $90 \mathrm{~min}$ of immersion of these wires into the solution, there was no visible $\mathrm{CaCO}_{3}$ precipitate for $0.5 \mathrm{mM}$ total calcium concentration. On the contrary, crystals of a few micrometres length were observed after $90 \mathrm{~min}$ immersion in a $2.5 \mathrm{mM}$ calcium CBS solution: an electrode covering apparently lower than $10 \%$ was then evaluated.

Thus, both calculations and observations demonstrate that, within $27 \mathrm{mM}$ CBS at $\mathrm{pH} \mathrm{7.4}$, no calcium carbonate precipitates below at least $0.8 \mathrm{mM}$ total calcium concentration.

After initial stabilization of background current in CBS and calibration with $3 \mathrm{mM}$ glucose or $0.02 \mathrm{mM} \mathrm{H} \mathrm{H}_{2} \mathrm{O}_{2}, 0.5 \mathrm{mM}$ calcium was added to the solution. An 18 and $30 \%$ decrease of the current was observed, respectively, for glucose and $\mathrm{H}_{2} \mathrm{O}_{2}$, reaching a new steady state after 15$30 \mathrm{~min}\left(t_{90 \%}\right)$ (Fig. 2). These sensors recovered their initial sensitivity after 15-30 min washing with calcium-free CBS solutions. Such calcium inhibition of sensor responses to glucose and hydrogen peroxide was observed both for freshly prepared sensors and for those used in calciumcontaining solutions and then rinsed in CBS solutions. 
When comparing calcium effect on several sensors, a linear correlation was observed between the residual glucose sensitivity and the initial sensor glucose sensitivity in the absence of calcium $\left(r^{2}=0.84, n=11\right.$ ) (Fig. 3(A)). Thus, the less sensitive sensors (1-3 nA mM-1 $\mathrm{mm}^{-2}$ ) were almost unaffected by the presence of $0.5 \mathrm{mM} \mathrm{Ca}$, whereas more sensitive ones presented a 5-17\% inhibition in the presence of $0.5 \mathrm{mM} \mathrm{Ca}$. Although responses to hydrogen peroxide are much less reproducible than glucose ones, since Pt anodes of such sensors cannot be polished mechanically, a linear correlation was also observed for $\mathrm{H}_{2} \mathrm{O}_{2}$ sensor response $\left(r^{2}=\right.$ 0.67, $n=9$ ) (Fig. 3(B)).

Calcium concentration effect on glucose and $\mathrm{H}_{2} \mathrm{O}_{2}$ response was evaluated in the $0.5-2 \mathrm{mM}$ calcium range by plotting glucose and $\mathrm{H}_{2} \mathrm{O}_{2}$ calibration curves in CBS solutions spiked with calcium: a linear correlation was observed between the relative sensitivity and the calcium concentration in CBS (Fig. 4). This batch of sensors being in the lower sensitivity range of those described in Fig. 3, they present a $0.5 \mathrm{mM} \mathrm{Ca}$ inhibition for glucose and $\mathrm{H}_{2} \mathrm{O}_{2}$ in the 2-5 and $7-17 \%$ ranges, respectively.

Although the effect of calcium on glucose and $\mathrm{H}_{2} \mathrm{O}_{2}$ responses presents some qualitative differences, Figs. 2-4 seem to indicate that the calcium inhibition mechanism should be common both to glucose and to hydrogen peroxide responses and

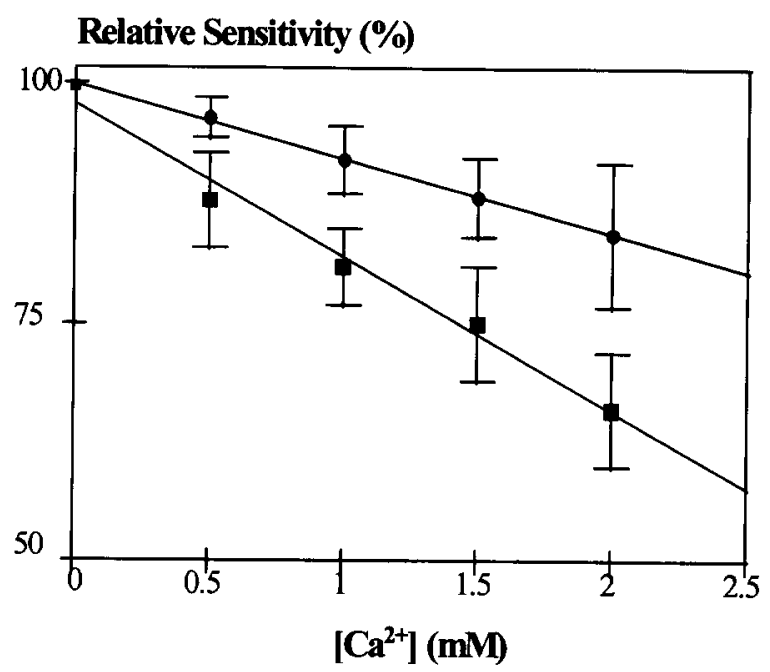

Fig. 4. Calcium concentration dependence of (1) glucose and (口) $\mathrm{H}_{2} \mathrm{O}_{2}$ glucose sensor sensitivities in CBS solutions. Mean values \pm standard deviations of relative sensitivities to glucose $(n=6)$ and $\mathrm{H}_{2} \mathrm{O}_{2}(n=4)$ as compared to their original values without calcium.

increase when sensors have higher sensitivity to both analytes. When considering all possible ratelimiting steps, glucose response depends upon: (1) oxygen transport through the PU outer layer;

(2) glucose transport through the PU outer layer; (3) glucose oxidation catalysed by glucose oxidase; (4) hydrogen peroxide transport through

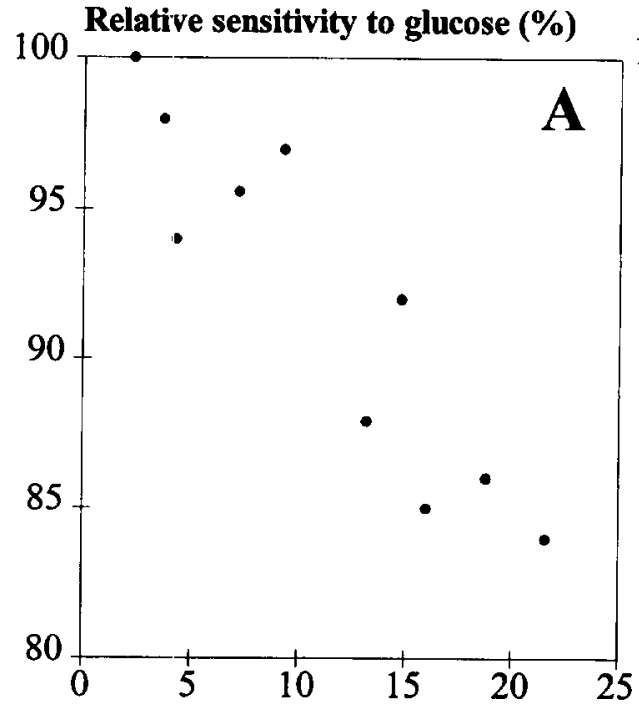

Sensitivity to glucose without $\mathbf{C a}(\mathbf{n A} / \mathbf{m M})$
Relative sensitivity to $\mathrm{H}_{2} \mathrm{O}_{2}(\%)$

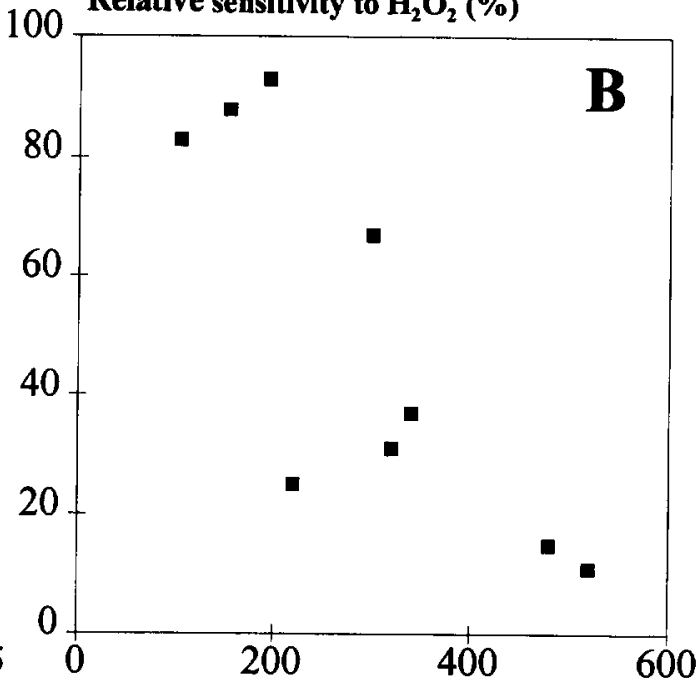

Sensitivity to $\mathrm{H}_{2} \mathrm{O}_{2}$ without $\mathrm{Ca}(\mathrm{nA} / \mathbf{m M})$

Fig. 3. Relative glucose sensor sensitivity either to (A) $3 \mathrm{mM}$ glucose or to (B) $0.02 \mathrm{mM} \mathrm{H}_{2} \mathrm{O}_{2}$ in $0.5 \mathrm{mM}$ calcium $C B S$ solution as compared to their original values in calcium free solution. 
CA, BSA-GA and Nafion inner layers; and (5) anodic detection of hydrogen peroxide.

Hydrogen peroxide response is controlled only by hydrogen peroxide transport through inner and outer layers and its anodic oxidation on Pt. Thus, any effect of calcium on oxygen transport and glucose oxidase activity has to be ruled out. Similarly, its seems very unlikely that calcium would act in the same manner on glucose and hydrogen peroxide transport through the outer PU layer: such a mechanism may indeed be different, i.e. micro porosity and homogenous permeability. Comparison of glucose and hydrogen peroxide responses before and after PU layer deposition has shown very different permeabilities for these two species (Sternberg et al., 1988): whereas sensitivity to glucose is decreased by a factor of about 30 when PU is deposited, sensitivity to hydrogen peroxide is only slightly reduced. Thus, it appears that calcium is probably inducing an inhibition of the common step to glucose and hydrogen peroxide responses, namely anodic detection of the latter.

\section{$\mathrm{H}_{2} \mathrm{O}_{2}$ responses of bare $\mathrm{Pt}-\mathrm{Ir}$ wires}

In order to detect the effect of calcium on hydrogen peroxide detection, bare $\mathrm{Pt}-\mathrm{Ir}$ wires were prepared. The $\mathrm{H}_{2} \mathrm{O}_{2}$ response of 11 bare $\mathrm{Pt}-\mathrm{Ir}$ wires was evaluated in CBS in the presence of calcium within the range $0.5-2.5 \mathrm{mM}$ : a $30-50 \%$ decrease of the sensitivity was observed as compared to the original value $I_{\mathrm{i}}$ in calcium-free CBS (Fig. 5(A)). A positive correlation between the

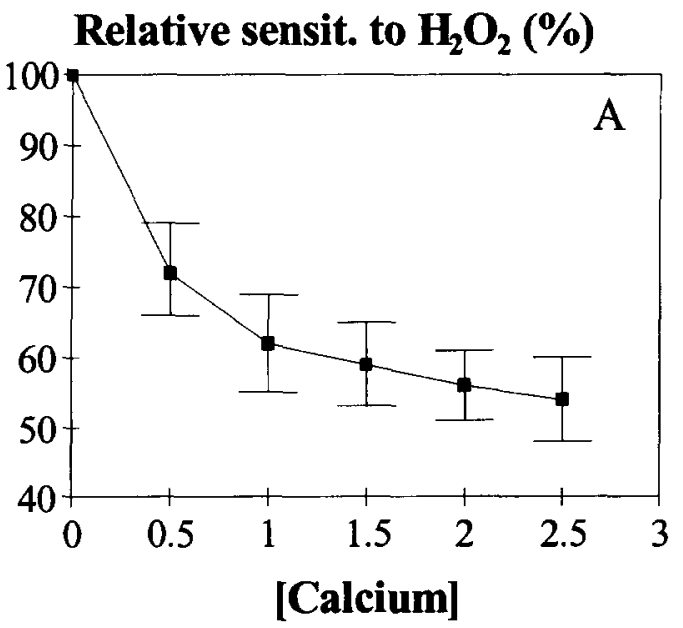

sensitivity decrease and the calcium concentrations in CBS was observed but calcium was found to yield a non-proportional inhibition of hydrogen peroxide detection and, apparently, to reach a maximum value for high calcium concentrations. In order to evaluate such maximum inhibition, inverse plots were drawn (Fig. 5(B)), giving, by linear regression, the following equation:

$$
\begin{aligned}
& I_{\mathrm{i}} / I(1 / \%)=0.019-0.0027 /\left[\mathrm{Ca}_{t o t}\right]\left(\mathrm{mM}^{-1}\right) \\
& \left(n=53, r^{2}=0.41\right)
\end{aligned}
$$

Thus, a maximum decrease of hydrogen peroxide sensitivity on bare $\mathrm{Pt}$-Ir wires was evaluated as $47 \%$. The half-maximum inhibition was obtained for about $0.3 \mathrm{mM}$ calcium in CBS: in such solution, calcium concentration was clearly below values necessary for carbonate or calcium hydroxide deposition. These sensors recovered their initial sensitivity after washing with calciumfree CBS solutions. The degree of inhibition of hydrogen peroxide responses of such bare $\mathrm{Pt}-\mathrm{Ir}$ wires, in the presence of $0.5 \mathrm{mM} \mathrm{Ca}$, i.e. $28 \pm$ $8 \%$ (Fig. 5(A)), was in the same range as for glucose sensors, i.e. $50 \pm 30 \%$ (Fig. 3(B)) or 12 $\pm 5 \%$ (Fig. 4). Apparently the inner and outer layers covering the Pt-Ir surface do not affect the calcium inhibition mechanism.

\section{$\mathrm{H}_{2} \mathrm{O}_{2}$ response of rotating $\mathrm{Pt}$ disk}

In order to differentiate any deposit invisible with optical microscopy from a reversible inhibition of the anodic oxidation of $\mathrm{H}_{2} \mathrm{O}_{2}$, we have performed

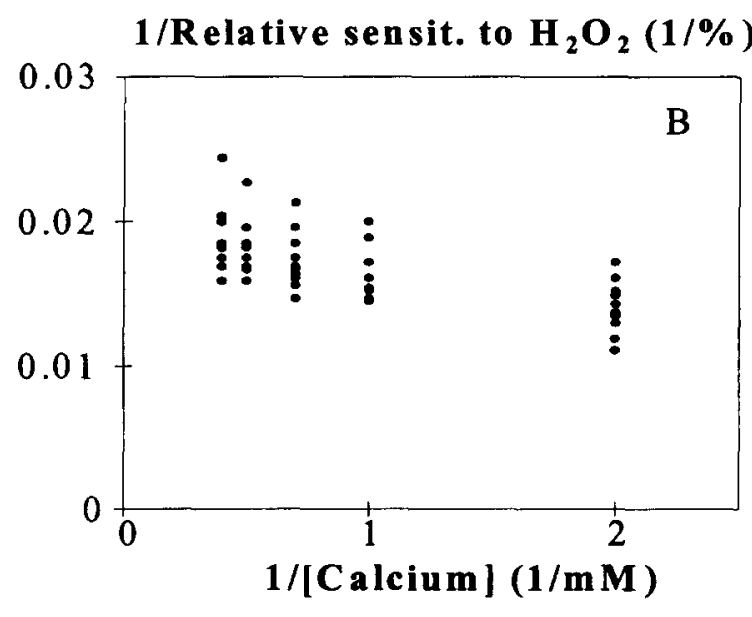

Fig. 5. Calcium concentration dependence of $\mathrm{H}_{2} \mathrm{O}_{2}$ sensitivities at bare Pt-Ir wires in CBS solutions: (A) relative sensitivity to $\mathrm{H}_{2} \mathrm{O}_{2}$ as compared to their original values without calcium (mean values \pm standard deviations, $n=$ $11,2-6 \mu \mathrm{M} \mathrm{H}_{2} \mathrm{O}_{2}$ solutions at $\left.\mathrm{pH} 7.4\right) ;(B)$ reciprocal plots of the same data $\left(r^{2}=0.41\right)$. 
experimental measurements of kinetic oxidation current $I_{\mathrm{k}}$ and of the kinetic oxidation constant $k_{\mathrm{f}}$ on a RDE.

All measurements were realized at a constant applied potential of $650 \mathrm{mV}$ against a $\mathrm{Ag} / \mathrm{AgCl}$ reference electrode. Voltamperometric studies have shown that this potential is indeed appropriate for $\mathrm{H}_{2} \mathrm{O}_{2}$ oxidation on rotating $\mathrm{Pt}$ electrodes: under our experimental conditions, i.e. $2 \mathrm{mV} / \mathrm{min}$, this plateau potential was found to be independent of the rotation speed (64-5000 r.p.m.) and not significantly modified by an increase of the hydrogen peroxide concentration in the $2-20 \mu \mathrm{M}$ range, or by the presence of $0.5 \mathrm{mM}$ calcium (Fig. 6). Finally, $650 \mathrm{mV}$ against $\mathrm{Ag} / \mathrm{AgCl}$ was found, under all our experimental conditions, to be situated on the plateau of the $\mathrm{H}_{2} \mathrm{O}_{2}$ anodic wave.

The general equation (1) for a slow electrode reaction contains both kinetic and mass transfer components (Bard \& Faulkner, 1980):

$$
I=n \mathrm{FA} k_{\mathrm{f}} C^{*} /\left(1+k_{\mathrm{f}} / m\right)
$$

where $k_{\mathrm{f}}$ is the heterogeneous electron transfer rate constant and $m$ is the mass transport coefficient. These two terms can be separated using reverse plots:

$$
1 / I=1 / I_{\mathrm{k}}+1 / I_{1, \mathrm{c}}
$$

where $I_{\mathrm{k}}$ is the kinetic current, i.e. the current at infinite rotation rate in the absence of any mass transfer limitation, and $I_{1, c}$ is the current under limiting current conditions. When using a RDE, $I_{1, \mathrm{c}}$ is defined by the Levich equation:

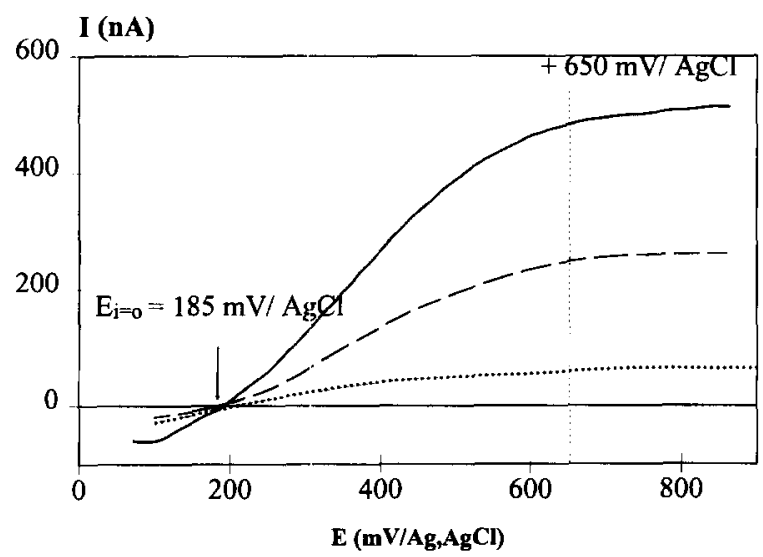

Fig. 6. Voltammetric curves in CBS solutions contain-

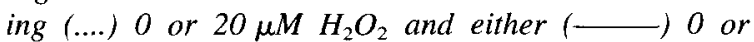
(-. -. -) $0.5 \mathrm{mM} \mathrm{Ca}$. Unpolished Pt RDE (1250 r.p.m.), $2 \mathrm{mV} / \mathrm{min}$ potential scan.

$$
I_{1, \mathrm{c}}=0.620 n \mathrm{~F} A D_{0}^{2 / 3} \omega^{1 / 2} \nu^{-1 / 6} C^{*}
$$

where $A$ is the electrode active area, $D_{0}$ the analyte diffusion coefficient, $\nu$ the cinematic viscosity, $\omega$ the disk electrode rotation speed and $C^{*}$ the analyte bulk concentration. As kinetic current $I_{\mathrm{k}}$ in Eq. (2) is proportional to $k_{\mathrm{f}}$ :

$$
I_{\mathrm{k}}=n \mathrm{~F} A k_{\mathrm{f}} C^{*}
$$

Eq. (2) becomes:

$$
\begin{aligned}
1 / I & =1 /\left(n \mathrm{~F} A k_{\mathrm{f}} C^{*}\right) \\
& +1 /\left(0 \cdot 620 n \mathrm{~F} A D_{0}^{2 / 3} \omega^{1 / 2} \nu^{-1 / 6} C^{*}\right)
\end{aligned}
$$

Thus, $I / \omega^{1 / 2} C^{*}$ is a constant only when $I_{\mathrm{k}}$ or $k_{\mathrm{f}}$ are large, i.e. when electrode reaction is rapid. When this is not the case a plot of $I$ versus $\omega^{1 / 2}$ (Levich plot) will be curved and reach a maximum $I_{\mathrm{k}}$. A plot of $1 / I$ versus $1 / \omega^{1 / 2}$ (Koutecky-Levich, KL, plot) should be linear and extrapolated at infinite rotation rate to yield $1 / I_{\mathrm{k}}$. Furthermore, the slope of a KL plot, i.e. $1 /\left(0.620 n \mathrm{~F} A D_{0}^{2 / 3} \nu^{-1 / 6} C^{*}\right)$, is directly related to the reciprocal of the electrode area $A$ and should be modified by its variation, for example by crystal deposits.

Levich plots, i.e. $\left(I-I_{0}\right)$ versus $\omega^{1 / 2}$, were found not to be linear, except at low rotation rate. They show a horizontal asymptote for highest rotation rates. This demonstrates the limiting role played by electrochemical kinetics during the establishment of the steady-state response of the glucose sensor.

As for experiments realized on Pt-Ir wires, addition of $0.5 \mathrm{mM}$ calcium chloride yielded a significant decrease of $\mathrm{H}_{2} \mathrm{O}_{2}$ kinetic oxidation current. KL plots, i.e. $1 /\left(I-I_{0}\right)$ versus $\omega^{-1 / 2}$ where, for each rotation rate, steady-state current $I$ was corrected from its background value $I_{0}$ in the absence of hydrogen peroxide, were found to be linear with identical slopes to those observed in the absence of calcium (Fig. 7 and Table 2). This demonstrates that the Pt disk active area $A$ is not significantly modified in the presence of $0.5 \mathrm{mM}$ calcium. Furthermore, both kinetic oxidation current $I_{\mathrm{k}}$ at infinite rotation speed and kinetic oxidation constant $k_{\mathrm{f}}$ decrease reversibly by $c a 30-45 \%$ when $0.5 \mathrm{mM}$ calcium is added to CBS. These results were observed on both unpolished and polished platinum disk and within 2 or $20 \mu \mathrm{M}$ hydrogen peroxide solutions: the main effects of electrode polishing were the increase of $k_{\mathrm{f}}$ and the increase of the inhibition effect of $0.5 \mathrm{mM} \mathrm{Ca}$, which reached $30-35$ and 
$1 /\left(\mathbf{I}-\mathbf{I}_{0}\right)\left(\mathrm{nA}^{-1}\right)$

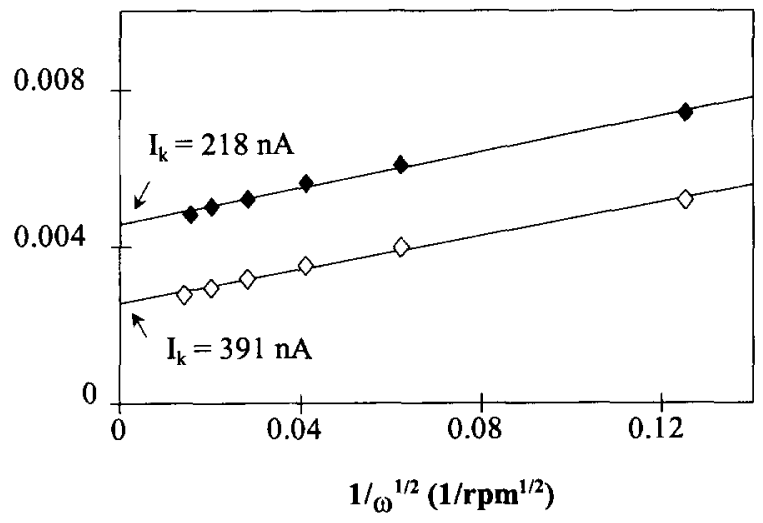

Fig. 7. Koutecky-Levich curves in the 64-5000 r.p.m.

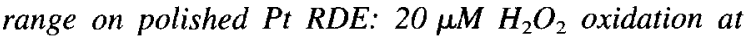
$650 \mathrm{mV} / \mathrm{AgCl}$ in $\mathrm{CBS}$ at $25^{\circ} \mathrm{C}$ containing either $(\diamond) 0$ or (\$) $0.5 \mathrm{mM}$ calcium. Each steady-state current I was corrected from its background values $I_{0}$ at each rotation rate.

$35-45 \%$ on unpolished and polished Pt RDE, respectively. Such inhibition of hydrogen peroxide oxidation on a Pt RDE, by the addition of $0.5 \mathrm{mM} \mathrm{Ca}{ }^{2+}$, is very similar, both in amplitude and reversibility, to what was observed on bare Pt-Ir wires (Fig. 5(A)). On the other hand, organic layers, such as those covering the Pt-Ir surface in these glucose sensors, do not appear to decrease the amplitude of the $0.5 \mathrm{mM} \mathrm{Ca}$ inhibition, which is in the $10-90 \%$ range (Fig. $3(B)$ ). Finally, the complexity of the $\mathrm{H}_{2} \mathrm{O}_{2}$ oxidation mechanism on $\mathrm{Pt}$ is further evidenced by the $\mathrm{H}_{2} \mathrm{O}_{2}$ concentration dependence of $k_{\mathrm{f}}$ : the measured kinetic constant reaches 1.85 and 3.3 $\times 10^{-3} \mathrm{~cm} / \mathrm{s}$ in 2 and $20 \mu \mathrm{M} \mathrm{H}_{2} \mathrm{O}_{2}$, respectively (Table 2).

\section{Chelatant effect on calcium inhibition}

In biological fluids, calcium is present both under ionized and complexed forms, so it seems interesting to study the effect of different chelating agents on the calcium inhibition of $\mathrm{H}_{2} \mathrm{O}_{2}$ response. Under physiological conditions, organic acids, i.e. pyruvate, lactate, $\alpha$ ketoglutarate and $\beta$ hydroxybutyrate, show small affinity to calcium and have no effect on the inhibition of $\mathrm{H}_{2} \mathrm{O}_{2}$ oxidation by this cation.

Chelating agents which present higher affinity to calcium, i.e. oxalic and citric acids and EDTA, have also been studied. They have been chosen for the calcium dissociation constant values of $\mathrm{CaC}_{2} \mathrm{O}_{4}, \mathrm{CaHCit}^{-}$and $\mathrm{CaEDTA}^{2-}$, i.e. $10^{-3 \cdot 0}$, $10^{-4 \cdot 8}$ and $10^{-7 \cdot 8}$, respectively (apparent constants at $\mathrm{pH} 7.4$ ). In the absence of calcium, 0.25 and $0.5 \mathrm{mM}$ oxalic and citric acid yielded only a small modification of $\mathrm{H}_{2} \mathrm{O}_{2}$ response at a polished rotating Pt disk. On the other hand, EDTA plays an important promoting role on $\mathrm{H}_{2} \mathrm{O}_{2}$ oxidation: $0.25 \mathrm{mM}$ EDTA addition gives a $65 \%$ increase of $20 \mu \mathrm{M} \mathrm{H}_{2} \mathrm{O}_{2}$ response (Fig. 8). In the presence of $0.5 \mathrm{mM}$ calcium, $0.25-0.75 \mathrm{mM}$ oxalic and citric acids still have no effect on $\mathrm{H}_{2} \mathrm{O}_{2}$ response and do not permit one to regain the original sensitivity to $\mathrm{H}_{2} \mathrm{O}_{2}$. On the contrary, addition of EDTA enables one to outmatch the original sensitivity obtained in the absence of calcium. No direct oxidation of EDTA was observed within the $0.2-1.0 \mathrm{mM}$ range, using $50 \mathrm{mV} / \mathrm{s} \mathrm{cyc}$ lic voltammetry in CBS.

$\mathrm{KL}$ plots, i.e. $1 /\left(I-I_{0}\right)$ versus $1 / \omega^{1 / 2}$ on a polished rotating $\mathrm{Pt}$ disk in the presence of $1 \mathrm{mM}$ EDTA, confirm the promoting effect of this chelating species (Fig. 9). Extrapolation to infinite rotation rate shows that, in the absence as well

TABLE 2 Effects of $0.5 \mathrm{mM}$ calcium addition to CBS on hydrogen peroxide kinetic parameters, as determined on $\mathrm{KL}$ plots similar to Fig. 6: mean obtained for three to six experiments, each using six rotation rate values in the $100-5000$ r.p.m. range

\begin{tabular}{|c|c|c|c|c|c|c|c|c|c|c|}
\hline \multirow[b]{2}{*}{$R D E$} & \multirow{2}{*}{$\begin{array}{l}\mathrm{H}_{2} \mathrm{O}_{2} \\
(\mu M)\end{array}$} & \multirow{2}{*}{$\begin{array}{l}E D T A \\
(m M)\end{array}$} & \multicolumn{2}{|c|}{$\begin{array}{c}I_{K} / A \\
\left(n A / m m^{2}\right)\end{array}$} & \multicolumn{2}{|c|}{$\left(10^{-k_{f}} \mathrm{~cm} / \mathrm{s}\right)$} & \multicolumn{2}{|c|}{$\begin{array}{c}\text { KL slope } \\
\left(\mathrm{nA}^{-1} \mathrm{rad}^{1 / 2} \mathrm{~s}^{1 / 2}\right)\end{array}$} & \multicolumn{2}{|c|}{$r^{2}$} \\
\hline & & & No $\mathrm{Ca}$ & $\mathrm{Ca}$ & No $\mathrm{Ca}$ & $\mathrm{Ca}$ & No $\mathrm{Ca}$ & $\mathrm{Ca}$ & $\mathrm{No} \mathrm{Ca}$ & $\mathrm{Ca}$ \\
\hline \multirow[t]{3}{*}{ Polished } & 2 & 0 & 7.0 & $4 \cdot 3$ & 1.85 & 1.20 & 0.09 & 0.09 & 0.99 & 0.99 \\
\hline & 20 & 0 & 124 & 69 & $3 \cdot 3$ & 1.8 & $0 \cdot 10$ & 0.10 & 0.99 & 0.99 \\
\hline & 20 & 1 & 229 & 205 & 6 & $5 \cdot 4$ & 0.09 & 0.09 & 0.99 & 0.99 \\
\hline \multirow{2}{*}{$\begin{array}{l}\text { Not } \\
\text { polished }\end{array}$} & 2 & 0 & $3 \cdot 0$ & $2 \cdot 1$ & 0.80 & 0.56 & 0.087 & 0.092 & 0.99 & 0.99 \\
\hline & 20 & 0 & 33 & 21 & 0.85 & 0.56 & 0.10 & 0.11 & 1.00 & 0.96 \\
\hline
\end{tabular}




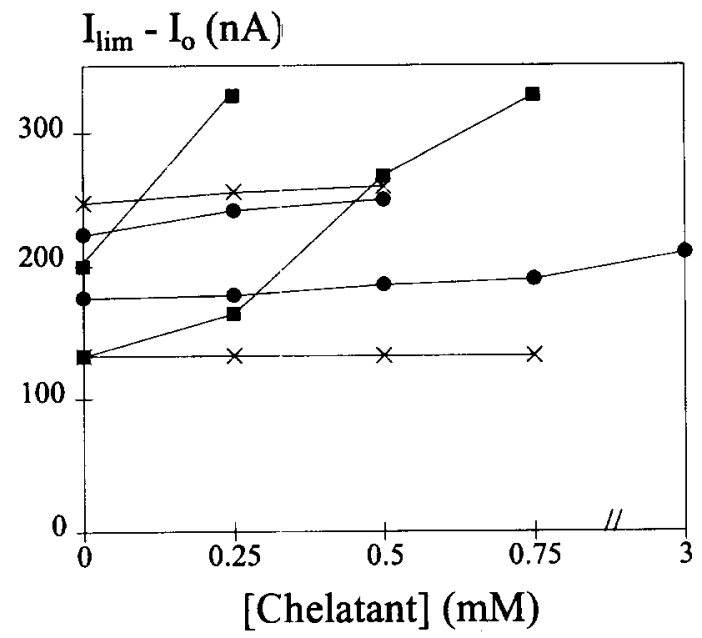

Fig. 8. (ם) EDTA, (O) citrate and ( $\times$ ) oxalate concentration effect on polished $P t$ disk steady-state response $\left(I_{\mathrm{lim}}-I_{0}\right)$ to $20 \mu \mathrm{M} \mathrm{H}_{2} \mathrm{O}_{2}$ in $\mathrm{CBS}$ solution containing either (- - $) 0$ or $(-\cdot-) 0.5 \mathrm{mM}$ calcium, at $650 \mathrm{mV} / \mathrm{AgCl}$ and 1250 r.p.m. rotation rate.

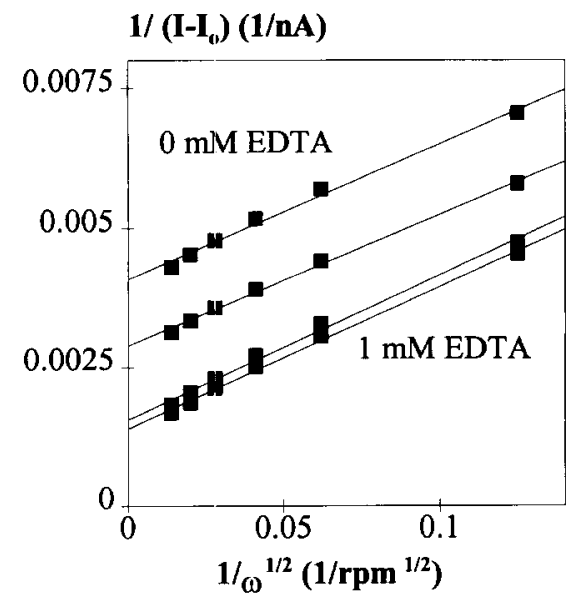

Fig. 9. Koutecky-Levich curves in the 64-5000 r.p.m. range on polished $\mathrm{Pt} \mathrm{RDE}: 2 \mathrm{O} \mu \mathrm{M} \mathrm{H}_{2} \mathrm{O}_{2}$ oxidation at $650 \mathrm{mV} / \mathrm{AgCl}$ in $\mathrm{CBS}$ at $25^{\circ} \mathrm{C}$ containing either ( $\square$ ) 0 or (ロ) $1 \mathrm{mM} \mathrm{EDTA}$ and (—) 0 or $0.5 \mathrm{mM}$ (--) calcium chloride. Each steady-state current I was corrected from its background values $I_{0}$ at each rotation rate.

as in the presence of $0.5 \mathrm{mM}$ calcium, addition of $1 \mathrm{mM}$ EDTA increases by a factor of approximately 2 the $\mathrm{H}_{2} \mathrm{O}_{2}$ oxidation rate $k_{\mathrm{f}}$ (Table 2).

The comparison between the magnitude of the $1 \mathrm{mM}$ EDTA-promoting effect and $0.5 \mathrm{mM} \mathrm{Ca}^{2+}$ or the $\mathrm{CaL}_{n}$-inhibiting effect on $\mathrm{H}_{2} \mathrm{O}_{2}$ oxidation shows we have two antagonist mechanisms: one decreasing $\mathrm{H}_{2} \mathrm{O}_{2}$ kinetic oxidation constant $k_{\mathrm{f}}$ by
$\mathrm{Ca}^{2+}$ or $\mathrm{CaL}_{n}$ when $\mathrm{L}$ is oxalate or citrate and another one increasing $k_{\mathrm{f}}$ in the presence of EDTA.

\section{CONCLUSION}

Within small species capable of reaching glucose biosensor platinum working electrode from biological samples, we have shown that calcium inhibits significantly glucose responses. Calcium $(0.5 \mathrm{mM})$ addition inhibits relatively slowly $\left(t_{90 \%}\right.$ $=15$ to $30 \mathrm{~min}$ ) biosensor responses to both glucose and hydrogen peroxide $(0-45$ and $30-$ $90 \%$, respectively). Such inhibition is reversible, i.e. disappears after 15-30 min washing in CBS solutions, and appears to be correlated to sensor sensitivities. It is limited to $0-7$ and $10-20 \%$ for glucose and hydrogen peroxide, respectively, when sensors are prepared and selected for a limited sensitivity, as it is often necessary for in vivo implantation. Calcium acts similarly on both enzymatic-electrochemical (glucose) and electrochemical (hydrogen peroxide) responses. Taking into account the very different PU permeabilities to glucose and hydrogen peroxide, it seems that calcium is interfering with the anodic oxidation of hydrogen peroxide. Results obtained on bare $\mathrm{Pt}$-Ir wires indicate that the interaction with calcium is reversible and presents an amplitude within the range observed on glucose sensors. On the contrary, this inhibition is not proportional to the total calcium concentration: it reaches a $47 \%$ maximum value for calcium concentration higher than $3 \mathrm{mM}$ in CBS, i.e. in over-saturated calcium solutions in which the Pt surface is likely to be partially covered by carbonate crystals. Experiments performed on rotating platinum disks clearly show that under-saturated calcium solutions decrease the $\mathrm{H}_{2} \mathrm{O}_{2}$ kinetic oxidation rate but do not affect the active electrode area. Multiequilibrium calculations, optical microscopy observations and KL plots on rotating platinum disks indeed rule out the occurrence of calcium carbonate deposits in $0.5 \mathrm{mM}$ calcium CBS solutions at $\mathrm{pH} 7 \cdot 4$.

Calcium complexation by different chelating agents, such as oxalate and citrate, indicates that, even when complexed, calcium inhibits electrochemical $\mathrm{H}_{2} \mathrm{O}_{2}$ oxidation. However, this inhibiting effect may be partly or completely compensated by a promoting effect of EDTA.

Several hypotheses for possible reactions 
between platinum, hydrogen peroxide and calcium can be proposed:

(1) A catalytic dismutation of $\mathrm{H}_{2} \mathrm{O}_{2}$, thermodynamically unstable, is unlikely. Measurements of $\mathrm{H}_{2} \mathrm{O}_{2}$ kinetic oxidation constant on $\mathrm{Pt}$ rotating disks are reproducible within several hours: this rules out $\mathrm{H}_{2} \mathrm{O}_{2}$ decrease even at low concentration levels such as $2 \mu \mathrm{M}$.

(2) Lowry et al. (1994) described a homogenous reaction between ascorbic acid and hydrogen peroxide catalysed by metallic ions traces, thus confirming the hypotheses of Hand \& Greisen (1942), Timberlake (1960) and De Chatelet et al. (1972). In our experiments such homogenous chemical reaction of hydrogen peroxide could be considered only if this reaction was fast and not complete. Furthermore, we have observed the calcium inhibition of hydrogen peroxide response even in the absence of ascorbate.

(3) A heterogeneous chemical reaction between hydrogen peroxide and a solid at the platinum surface may occur. Electrochemical oxidation of hydrogen peroxide has been studied by Zhang \& Wilson (1993) on similar $\mathrm{Pt}$ disk and $\mathrm{Pt}-\mathrm{Ir}$ wires, within phosphate buffer saline solution either at $\mathrm{pH}$ equal to 7.4 or fixed in the 4-13 range by additions of $\mathrm{HCl}$ or $\mathrm{NaOH}$. It has been found that the oxidation rate constant $k_{\mathrm{f}}$ of $0 \cdot 1-3 \mathrm{mM}$ hydrogen peroxide solutions is in the $5-7 \cdot 10^{-6} \mathrm{~cm} / \mathrm{s}$ range, much lower than the $2-3 \cdot 10^{-3} \mathrm{~cm} / \mathrm{s}$ values observed in this work (Table 2). The rate-limiting step has been estimated by Zhang \& Wilson (1993) to be either an electron-transfer reaction or preceding chemical reaction that would occur between hydrogen peroxide and the $\mathrm{Pt}(\mathrm{PtO})$ surface. At the + $650 \mathrm{mV} / \mathrm{Ag}-\mathrm{AgCl}$ applied potential and at $\mathrm{pH} 7 \cdot 4$, the electrode is partially covered by platinum oxides such as $\mathrm{PtO}, \mathrm{PtO}_{2}$ and $\mathrm{Pt}(\mathrm{OH})_{2}$. The amount of such species on the Pt surface may depend upon experimental conditions and influence $k_{\mathrm{f}}$.

(4) Pacault (1958) describes the formation of calcium peroxides between calcium hydroxide and $\mathrm{H}_{2} \mathrm{O}_{2}$ but no kinetic or thermodynamic data are given on such a reaction.
In conclusion, if there is a chemical reaction of $\mathrm{H}_{2} \mathrm{O}_{2}$ with calcium it should be relatively slow, i.e. reach an equilibrium within 15-30 min, and be not total even in the presence of a large excess of calcium compared to hydrogen peroxide, i.e. $3 \mathrm{mM}$ versus $2 \mu \mathrm{M}$.

This work demonstrates the importance of biosensor detection, especially the electrochemical one, in the understanding and control of biosensor inhibition mechanisms. This work does not prove that free or complexed calcium is the only factor responsible for biosensor inhibition in biological fluids. In fact, the amplitude of the observed inhibition of glucose response in the presence of $0.5 \mathrm{mM} \mathrm{Ca}$, i.e. $0-7 \%$, is significantly lower than the inhibition observed when similar sensors are implanted subcutaneously or placed in blood serum, i.e. $50-80 \%$. It nevertheless shows that calcium is likely to contribute to such in vivo inhibition: as the metal surface state and covering layers may modify such a calcium effect, we recommend assessing its value for each type of glucose sensor developed for either in vivo or in vitro measurements if the latter are performed in calcium-containing samples.

\section{ACKNOWLEDGEMENTS}

The authors thank National Institutes of Health (DK30718) as well as 'Aides aux Jeunes Diabétiques' for financial support, Dr Y. Zhang and G. Wilson for providing some of the glucose sensors used in this work and Dr J. M. Mouchel for providing CINEQ software.

\section{REFERENCES}

Bard, A. J. \& Faulkner, L. R. (1980). Electrochemical Methods: Fundamentals and Applications. J. Wiley, New York.

Bindra, D. S., Zhang, Y., Wilson, G. S., Sternberg, R., Thévenot, D. R., Moatti, D. and Reach, G. (1991) Design and in vitro studies of needle type glucose sensor for subcutaneous monitoring. Anal. Chem. 63, 1692-1696.

Charlot, G. (1969). Les Réactions Chimiques en Solution: L'analyse Qualitative Minérale. Masson, Paris.

De Chatelet, L. R., Cooper, M. R. and McCall, C. E. (1972) Antimicrob. Agents Chemother. 1, 12-16.

Fischer, U., Ertle, R., Abel, P., Rebrin, K., Brunstein, E., Hahn Von Dorsche, H. and Freyse, E. J. (1987) 
Assessment of subcutaneous glucose concentration: validation of the wick technique as a reference for implanted electrochemical sensors in normal and diabetic dogs. Diabetologia 30, 940-945.

Hand, D. B. and Greisen, E. C. (1942) Oxidation and reduction of vitamin C. J. Am. Chem. Soc. 64, $358-361$.

Hanning, I., Vadgama, P., Covington, A. K. and Alberti, K. G. M. M. (1986) Improved blood compatibility at a glucose enzyme electrode used for extracorporeal monitoring. Analyt. Lett. 19, 461478.

Kerner, W., Linke, B. \& Kiwit, M. (1993). Sensitivities to glucose of electroenzymatic sensors are lower in vivo than in vitro: possible mechanisms responsible for this observation. Biomedical Concerted Action for Chemical Sensors for in vivo Monitoring, First Workshop, Fontainebleau, France.

Kotrly, S. \& Sucha, L. (1985). Handbook of Chemical Equilibria in Analytical Chemistry. Ellis Horwood, Chichester.

Koudelka, M., Rohner-Jeanrenaud, F., Terrettaz, J., Bobbioni-Harsch, E., De Rooij, N. F. and Jeanrenaud, B. (1991) In vivo behaviour of hypodermically implanted microfabricated glucose sensors. Biosensors \& Bioelectronics 6, 31-36.

Lobel, E. and Rishpon, J. (1981) Enzyme electrode for the determination of glucose. Anal. Chem. 53, 51-53.

Lowry, J. P., McAteer, K., El Atrash, S., Duff, A. and O'Neill, D. (1994) Characterization of glucose oxidase-modified poly(phenylenediamine)-coated electrodes in vitro and in vivo: homogeneous interference by ascorbic acid in hydrogen peroxide detection. Anal. Chem. 66, 1754-1761.

Mascini, M. and Selleri, S. (1989) Glucose biosensor with extended linearity. Analyt. Lett. 22, 1429 1449.

Pacault, A. (1958). Bioxyde ou peroxyde d"hydrogène ou eau oxygénée. In Nouveau traité de Chimie Générale, ed. Pascal. Masson, Paris.

Pickup, J. C. and Thévenot, D. R. (1993) European achievement in sensor research dedicated to in vivo monitoring, (a) Glucose. Adv. Biosensors suppl. 1, 202-225.

Pickup, J. C., Shaw, G. W. and Claremont, D. J. (1989) In vivo molecular sensing in diabetes mellitus: an implantable glucose sensor with direct electron transfer. Diabetologia 32, 213-217.

Shichiri, M., Kawamori, R., Yamasaki, Y., Hakui, N. and Abe, H. (1982) Wearable artificial endocrine pancreas with needle type glucose sensor. The Lancet 2, 1129-1131.

Sigg, L., Stumm, W. \& Behra, P. (1992). Chimie des Milieux Aquatiques. Chimie des Eaux Naturelles et des Interfaces dans l'Environnement. Masson, Paris.

Siggaard-Andersen, O., Jorgen, T. and Fogh-Andersen, N. (1983a) What is 'ionized calcium'? Scand. $J$. Clin. Invest. 43, 11-16.

Siggard-Andersen, O., Thode, J. and Fogh-Andersen, N. (1983b) Normograms for calculating the concentration of ionized calcium of human blood plasma for total calcium, total protein and/or albumin, and $\mathrm{pH}$. Scand. J. Clin. Invest. 43, 57-64.

Sternberg, R., Barrau, M. B., Gangiotti, L. and Thévenot, D. R. (1988) Study and development of multilayer needle-type enzyme based glucose microsensors. Biosensors 4, 27-40.

Timberlake, C. F. (1960) Metallic components of fruit juice IV oxidation and stability of ascorbic acid in blackcurrant juice. J. Sci. Food Agric. 11, 268-273.

Wilson, G. S., Reach, G. and Thévenot, D. R. (1991) Biosensors for intracorporal measurements: problems and strategies. Biochem. Soc. Trans. 19, 9-11.

Zhang, Y. and Wilson, G. S. (1993) Electrochemical oxidation of $\mathrm{H}_{2} \mathrm{O}_{2}$ on $\mathrm{Pt}$ and $\mathrm{Pt} / \mathrm{Ir}$ electrodes in physiological buffer and its applicability to $\mathrm{H}_{2} \mathrm{O}_{2}$ based biosensors. J. Electroanal. Chem. 345 , 253-273.

Zhang, Y., Hu, Y., Wilson, G. S., Moatti-Sirah, D., Poitout, V. and Reach, G. (1994) Elimination of the acetaminophen interference in an implantable glucose sensor. Anal. Chem. 66, 1183-1188. 